\title{
LAYANAN TERAPUNG DINAS PERPUSTAKAAN DAN KEARSIPAN DI PULAU GUSUNG KABUPATEN KEPULAUAN SELAYAR
}

\author{
Saenal Abidin ${ }^{1} \&$ Rahmayanti $^{2}$ \\ ${ }^{1}$ Dosen UIN Alauddin Makassar \\ 2UIN Alauddin Makassar \\ Correspondence email: saenal.abidin@uin-alauddin.ac.id
}

\begin{abstract}
This research discusses "The Effectiveness of the Floating Mobile Library Service of the Library and Archives Service in Gusung Island, Selayar Islands Regency". The main problem in this research is how the effectiveness of the floating mobile library services of the Library and Archives Service in Gusung Island, Selayar Islands Regency. The purpose of this research is to determine the effectiveness of the floating mobile library services of the Library and Archives Service in Gusung Island, Selayar Islands Regency and to find out the efforts which is carried out to improve the floating mobile library services of the Library and Archives Service in Gusung Island, Selayar Islands Regency. This type of research uses descriptive research with a qualitative approach and uses data collection methods by observation, interviews, and documentation. The results of this study indicate that the effectiveness of the service floating mobile library The Library Service on Gusung Island, Selayar Islands Regency is divided into 4 elements. Based on the facilities, the floating mobile library has adequate facilities. Based on the collection, the floating mobile library provides various collections of library materials that are tailored to the needs of the user. Based on its services, floating mobile library services are carried out once or twice a week and often competitions are held. Based on the library, this floating mobile library is well received by the community and children in the archipelago are also getting more active in reading.
\end{abstract}

Keywords: Services, Floating library

\begin{abstract}
Abstrak
Penelitian ini membahas tentang "Efektivitas Layanan Perpustakaan Keliling Terapung Dinas Perpustakaan dan Kearsipan di Pulau Gusung Kabupaten Kepulauan Selayar". Pokok permasalahan dalam penelitian ini adalah bagaimana keefektifan layanan perpustakaan keliling terapung Dinas Perpustakaan dan Kearsipan di Pulau Gusung Kabupaten Kepulauan Selayar.Tujuan penelitian ini adalah untuk mengetahui keefektifan layanan perpustakaan keliling terapung Dinas Perpustakaan dan Kearsipan di Pulau Gusung Kabupaten Kepulauan Selayar dan untuk mengetahui upaya-upaya yang dilakukan untuk meningkatkan layanan perpustakaan keliling terapung Dinas Perpustakaan dan Kearsipan di Pulau Gusung Kabupaten Kepulauan Selayar. Jenis penelitian ini menggunakan jenis penelitian deskriptif dengan melakukan pendekatan kualitatif dan menggunakan metode pengumpulan data dengan observasi, wawancara, dan dokumentasi.Hasil penelitian ini menunjukkan bahwa keefektifan layanan perpustakaan keliling
\end{abstract}


terapung Dinas Perpustakaan di Pulau Gusung Kabupaten Kepulauan Selayar dibagi menjadi 4 unsur. Berdasarkan fasilitasnya, perpustakaan keliling terapung memiliki fasilitas yang memadai. Berdasarkan koleksinya, perpustakaan keliling terapung menyediakan berbagai macam koleksi bahan pustaka yang disesuaikan dengan kebutuhan pengguna. Berdasarkan layanannya, layanan perpustakaan keliling terapung dilaksanakan satu sampai dua kali dalam seminggu dan seringkali diadakan lomba-lomba. Berdasarkan pemustakanya, perpustakaan keliling terapung ini diterima dengan baik oleh masyarakat dan anak-anak di daerah kepulauan juga semakin giat membaca.

Kata Kunci: Layanan, Perpustakaan terapung 


\section{A. Pendahuluan}

Perpustakaan memiliki peran yang sangat penting dalam meningkatkan taraf hidup masyarakat, yaitu sebagai wahana belajar bagi seluruh masyarakat untuk mengembangkan potensi mereka agar menjadi manusia yang beriman, bertakwa, berilmu, berakhlak mulia, dan kreatif. Pelayanan perpustakaan merupakan bagian terpenting dari setiap kegiatan perpustakaan karena selalu berinteraksi dengan pemustaka. Pemustaka yang kemudian akan menilai kualitas perpustakaan tersebut berdasarkan pelayanan yang diberikan oleh pustakawan pada saat pemustaka pertama kali berkunjung ke perpustakaan. Jika layanan perpustakaan yang diberikan berjalan dengan baik atau sesuai dengan keinginan pemustaka, maka mereka akan merasa senang berkunjung ke perpustakaan tersebut. Ini merupakan penilaian tersendiri bagi pemustaka yang kemudian akan membuat citra perpustakaan semakin naik dan semakin bagus.

Jika sebuah perpustakaan memiliki koleksi bahan pustaka yang sesuai dengan kebutuhan pemustaka, memiliki layanan perpustakaan yang bagus, serta sarana dan prasarana yang mendukung dan yang terpenting dimanfaatkan oleh pemustaka, maka perpustakaan tersebut sudah dapat dikatakan berhasil. Layanan merupakan suatu bagian penting di dalam perpustakaan yang harus dilakukan evaluasi untuk mengetahui baik atau tidak layanan yang diberikan oleh pustakawan. Evaluasi layanan dapat dilihat dari banyak sudut pandang, salah satunya adalah efektivitas layanan. Efektivitas layanan dapat dinilai dari bagaimana suatu organisasi mencapai tujuannya, yaitu sistem layanan yang diberikan oleh perpustakaan dan menyediakan informasi yang dibutuhkan oleh pemustaka untuk mencapai kepuasan bagi pemustaka.

Layanan perpustakaan keliling tidak dimiliki oleh semua perpustakaan. Bisanya hanya perpustakaan kabupaten / kota, perpustakaan provinsi, dan perpustakaan nasional. Selain itu juga banyak organisasi-organisasi dan Lembaga Swadaya Masyarakat (LSM) yang peduli dengan minat baca masyarakat (Arsana, 2017: 1). Layanan perpustakaan keliling ini merupakan sebuah alternatif yang melakukan pelayanan menggunakan transportasi untuk menyediakan koleksi kepada pemustaka. Pemustaka tidak harus berpindah tempat untuk mendapatkan informasi karena pemustaka yang didatangi, sehingga memudahkan pemustaka mendapatkan informasi yang dibutuhkan (Rakib, 2017: 6). Perpustakaan keliling terapung ini merupakan bantuan/sumbangan dari Perpustakaan Nasional pada tahun 2009. Kapal ini pertama kali melayani masyarakat yang berada di pulau pada tahun 2010. Kapal ini dapat memuat 25 orang dan di dalamnya terdapat ratusan koleksi buku untuk dilayankan kepada para pengunjung. Petugas perpustakaan yang bertugas dalam pelayanan kapal keliling ini kurang lebih berjumlah lima orang.

Adanya perpustakaan terapung atau kapal keliling Dinas Perpustakaan dan Kearsipan membawa pengaruh bagi masyarakat yang tinggal di pulau-pulau kecil Kabupaten Kepulauan Selayar. Dengan adanya perpustakaan terapung ini maka 
masyarakat khususnya anak-anak mampu mengembangkan atau meningkatkan minat baca mereka, serta kebutuhan rekreasi intelektual mereka dapat terpenuhi. Pelayanan yang terdapat pada perpustakaan terapung ini menggunakan layanan yang hanya memperbolehkan masyarakat atau pemustaka membaca koleksi ditempat atau di sekitar kapal saja. Bentuk layanan yang digunakan ialah layanan terbuka, yaitu pemustaka diberikan kebebasan untuk memilih dan mengambil sendiri koleksi yang dibutuhkannya di rak, kemudian dibawa untuk dibaca di tempat atau sekitar kapal. Keberadaan perpustakaan keliling terapung ini membuat masyarakat yang tinggal di daerah pesisir juga mampu merasakan berkunjung dan membaca di perpustakaan, meskipun bukan perpustakaan tetap. Namun perpustakaan keliling terapung ini tidak setiap harinya melakukan pelayanan ke daerah pesisir, sehingga waktu layanan ke setiap pulau tidak menentu dan kurang efektif. Adapun koleksi yang tersedia di dalam perpustakaan keliling terapung ini tidak mempunyai waktu tertentu untuk diperbaharui.

\section{B. Metodologi}

Jenis penelitian yang digunakan adalah jenis penelitian deskriptif dengan melakukan pendekatan kualitatif, yaitu penelitian yang menggunakan metode wawancara agar dapat memberikan gambaran/informasi yang jelas tentang masalah yang diteliti oleh penulis yang diperoleh dari berbagai informan mengenai efektivitas pelayanan perpustakaan terapung dan kendala yang dihadapi dalam pelayanan perpustakaan terapung Dinas Perpustakaan dan Kearsipan di Pulau Gusung Kabupaten Kepulauan Selayar.Pengumpulan data dapat dilakukan dengan berbagai sumber dan berbagai cara. Teknik pengumpulan data dalam penelitian ini, antara lain observasi, wawancara, dokumentasi, reduksi data, penyajian data, penarikan kesimpulan.

\section{Hasil Penelitian}

Peneliti membagi keefektifan layanan perpustakaan keliling terapung ini ke dalam agian, antara lain berdasarkan fasilitas, berdasarkan koleksi, berdasarkan layanan, dan berdasarkan pemustaka.

\section{Berdasarkan Fasilitas}

Fasilitas sangat berperan penting di dalam suatu perpustakaan. Suatu perpustakaan membutuhkan fasilitas yang bagus dan lengkap agar pemustaka yang berkunjung merasa nyaman. Kenyamanan pemustaka adalah hal terpenting yang harus diperhatikan. Kelengkapan fasilitas dalam perpustakaan dapat menjadi tolak ukur keberhasilan suatu perpustakaan. Fasilitas pada perpustakaan keliling berbeda dengan fasilitas perpustakaan pada umumnya. Fasilitas merupakan salah satu unsur terpenting yang ada di dalam perpustakaan. Salah satu hal yang dapat menarik perhatian pemustaka adalah kelengkapan fasilitas perpustakaan, sehingga pemustaka merasa lebih nyaman membaca koleksi yang ada di perpustakaan. 


\section{Berdasarkan Koleksi}

Koleksi bahan pustaka merupakan bagian penting dari perpustakaaan. Salah satu unsur layanan perpustakaan adalah koleksi. Koleksi yang disediakan perpustakaan merupakan daya tarik tersendiri bagi pemustaka. Apabila koleksi yang disediakan menarik, maka pemustaka akan senang berkunjung keperpustakaan. Sama halnya dengan perpustakaan keliling terapung ini, koleksi juga merupakan penunjang dalam manarik perhatian pemustaka. Perpustakaan harus mampu menyediakan koleksi yang dibutuhkan oleh pemustaka.Berdasarkan hasil wawancara dengan beberapa informan, dapat diketahui bahwa koleksi yang tersedia di perpustakaan keliling terapung beraneka macam, antara lain buku, majalah, koran, dan ensklopedi. Buku-buku yang tersedia mulai dari kelas 000-900 dan kebanyakan yang disediakan adalah koleksi khusus anak-anak, karena pengunjung perpustakaan terapung ini dominan anak-anak TK-SD.

Semakin banyak koleksi yang disediakan, maka pemustaka semakin tertarik untuk datang ke perpustakaan. Bagi para pemustaka yang masih kecil (anak-anak), mereka akan senang jika disediakan banyak koleksi, terutama koleksi yang bergambar. Koleksi yang banyak menjadikan pemustaka bebas dalam memilih bahan bacaannya. Perpustakaaan juga seharusnya menyediakan koleksi-koleksi yang up to date (terbaru) dengan selalu memperbaharui atau mengganti koleksi yang mereka sediakan pada perpustakaan keliling terapung. Berdasarkan hasil wawancara dengan informan, dapat diketahui bahwa koleksi yang ada di perpustakaan keliling terapung itu selalu dilak;ukan penggantian setiap setahun sekali, tetapi tidak berlaku bagi koleksi yang memiliki banyak peminat. Koleksi yang banyak dibaca oleh pemustaka baru diganti apabila sudah rusak dan tidak bisa diperbaiki lagi.

Berdasarkan hasil wawancara dengan beberapa informan, dapat diketahui bahwa koleksi bahan pustaka yang ada di perpustakaan keliling terapung diperoleh dengan dua cara, yaitu pembelian dan sumbangan. Untuk pembelian, kantor atau instansi menganggarkan setiap tahunnya untuk pembelian buku. Anggaran tersebut sudah ditentukan sejak awal, yang mana koleksi untuk disimpan di kantor (perpustakaan menetap), layanan perpustakaan mobil keliling, dan layanan perpustakaan keliling terapung. Untuk sumbangan, diperoleh dari perpustakaan provinsi dan perpustakaan nasional (perpusnas). Tetapi koleksi yang ada di perpustakaan kebanyakan dari hasil pembelian.

\section{Berdasarkan Layanan}

Layanan juga merupakan salah satu bagian terpenting dalam perpustakaan. Layanan yang diberikan oleh perpustakaan harus sesuai dengan kebutuhan pengguna perpustakaan. Layanan akan berjalan dengan baik apabila system layanan yang digunakan sesuai dengan kebutuhan pemustaka.Dari hasil wawancara dengan kedua informan, dapat diketahui bahwa perpustakaan keliling terapung menggunakan system layanan terbuka, pemustaka bisa mengambil sendiri koleksi 
yang diinginkannya. Namun apabila pemustaka mengalami kesulitan, pustakawan yang bertugas tetap membantu. System layanan terbuka memudahkan pemustaka dalm mencari informasi yang mereka butuhkan. Pemustaka juga bebas dalam memilih koleksi yang mana saja yang mereka inginkan.

Pada layanan perpustakaan keliling terapung melibatkan beberapa orang yang telah ditentukan masing-masing tugasnya. Dengan banyaknya yang terlibat dalam pelayanan, maka makin banyak pula layanan-layanan yang disediakan. Dari hasil wawancara dengan kedua informan, dapat diketahui bahwa layann yang tersedia di perpustakaan keliling terapung ada 3, antara lain layanan baca, layanan sirkulasi, dan layanan referensi. Pemustaka bisa membaca di dalam kapal ataupun sekitaran kapal, pemustaka juga bisa meminjam koleksi bahan pustaka. Tetapi koleksi referensi tidak bisa dipinjamkan, hanya untuk dibaca di tempat saja. Koleksi referensi diberikan warna merah pada punggung bukunya sebagai tanda.

Pemustaka yang meminjam koleksi perpustakaan dapat mengembalikannya setelah kapal melakukan pelayanan di daerahnya lagi. Agar layanan berjalan efektif, perpustakaan keliling terapung harus memiliki jadwal pelayanan yang tetap atau menentu. Berdasarkan hasil wawancara dengan ketiga informan, dapat diketahui bahwa layanan perpustakaan keliling terapung dilaksanakan sebanyak satu sampai dua kali dalam seminggu, tetapi tidak menetapkan hari tertentu tergantung pada kondisi cuaca. Layanan sebaiknya dilaksanakan ketika cuaca sedang bagus, demi keselamatan bersama. Dalam melakukan pelayanan, perpustakaan sabaiknya bukan hanya sekedar memberikan koleksi bahan bahcaan kepada masyarakat. Perlu dilakukan kegiatan-kegiatan khusus yang berkaitan dengan edukasi agar pemustaka tidak merasa jenuh ketika kapal perpustakaan keliling terapung mendatangi daerah mereka.

\section{Berdasarkan Pemustaka}

Pemustaka merupakan salah satu unsur pokok dalam perpustakaan. Suatu perpustakaan berjalan dengan baik jika memiliki pemustaka. Keefektifan suatu perpustakaan juga dilihat dari segi jumlah pemustakanya. Pemustaka ialah penentu dalam keberhasilan suatu perpustakaan.

Dari hasil wawancara dengan kedua informan terkait dengan persyaratanpersyaratan bagi pemustaka, dapat diketahui bahwa perpustakaan keliling terapung tidak memberikan syarat-syarat khusus bagi pengunjung yang datang. Semua orang bisa masuk ke kapal perpustakaan keliling terapung, mulai dari anak-anak hingga orang dewasa. Kepuasan pemustaka merupakan target utama dalam kegiatan layanan. Pemustaka akan memberikan kesan yang baik kepada perpustakaan apabila pustakawan yang melayani juga melayani pemustaka dengan baik. Berdasarkan hasil wawancara dengan informan 1 dan 2 dapat diketahui bahwa layanan yang diberikan oleh pustakawan sudah sesuai dengan harapan pemustaka, dimana pustakawan yang bertugas bersikap ramah, menyampaikan sesuatu dengan 
baik-baik, serta membantu pemustaka yang mengalami kesulitan. Sikap seorang pustakawan merupakan salah satu penentu kenyamanan pemustaka dalam pelayanan perpustakaan. Pelayanan yang baik akan memberikan kesan yang baik pula kepada masyarakat. Penilaian masyarakat bergantung pada cara pustakawan melayaninya.

Dari hasil wawancara dengan keempat informan, dapat diketahui tanggapan masyaarakat dengan adanya layanan perpustakaan keliling terapung ini, masyarakat menerima dengan baik dan selalu antusias apabila kapal perpustakaan keliling datang ke daerah mereka. Salah satu bukti antusiasnya mereka adalah ketika melakukan pelayanan di daerah mereka, sebelum sampai disana mereka sudah menunggu di dermaga. Pemustaka khsusnya anak-anak juga sangat senang bisa membaca di perpustakaan, apalagi koleksi-koleksi yang disediakan sesuai dengan kebutuhan pemustaka.

\section{Pembahasan}

Perpustakaan keliling terapung diperuntukkan bagi masyarakat yang tinggal di daerah pulau. Layanan ini merupakan salah satu layanan yang disediakan oleh Dinas Perpustakaan dan Kearsipan Kabupaten Kepulauan Selayar agar informasi yang ada diperpustakaan dapat sampai kepada masyarakat, khususnya yang tidak terjangkau oleh perpustakaan tetap. Keefektifan layanan perpustakaan keliling terapung ini dapat dilihat dari fasilitas, koleksi, layanan, dan pemustaka.

\section{Berdasarkan Fasilitas}

Fasilitas yang disediakan pada perpustakaan keliling terapung memiliki perbedaan dengan perpustakaan menetap. Hal yang paling membedakan antara perpustakaan menetap dengan perpustakaan terapung ialah fasilitas utama yang digunakan. Pada perpustakaan keliling terapung meggunakan kapal untuk melayani pengunjungnya. Hal ini sesuai dengan yang dikemukakan oleh Ali (2006: 119) bahwa sarana dan prasarana pada perpustakaan keliling disesuaikan dengan lokasi keberadaan pemakai serta kondisi medan yang akan dikunjungi. apabila pemustaka berada pada daerah perairan, misalnya daerah sungai atau pantai maka akan dilayani dengan menggunakan kendaraan air, seperti perahu, kapal motor, dan sebagainya.

Kapal yang digunakan pada layanan perpustakaan keliling terapung ini mampu menampung cukup banyak orang atau pemustaka. Hal ini dapat dibuktikan dengan semua pengunjung perpustakaan yang ingin membaca di perpustakaan keliling terapung ini dapat masuk ke dalam kapal, yang menandakan bahwa kapal ini dapat memuat cukup banyak orang. Pemustaka hanya berdesak-desakan ketika mereka masing-masing mencari koleksi yang mereka butuhkan pada saat pertama kali masuk ke kapal perpustakaan keliling terapung karena terlalu antusias ketika kapal ini datang. Kapal perpustakaan keliling terapung selalu terjaga kebersihan ruang bacanya dan koleksi yang ada di rak tersusun dengan rapi. Kebersihan dan kerapian 
kapal ini menjadi satu penilaian tersendiri oleh pemustaka, karena tempat yang tidak bersih akan menjadikan pemustaka kurang nyaman dalam membaca.

\section{Berdasarkan Koleksi}

Koleksi yang ada perpustakaan keliling terapung ini selalu diperbaharui dengan koleksi-koleksi terbaru. Biasanya setiap setahun sekali diganti dengan koleksi yang baru. Hal ini sesuai dengan yang dikemukakan oleh Ali (2006: 123) bahwa dalam pemilihan koleksi di perpustakaan, sebaiknya memilih koleksi yang terbaru atau tahun terbitnya yang terbaru, atau minimal setahun atau dua tahun terakhir dan mengupayakan edisi yang terbaru. Ini juga dimaksudkan agar pemustaka mendapatkan informasi-informasi yang up to date (terbaru). Istiana (2014: 8) juga mengemukakan bahwa perpustakaan harus menyediakan koleksi yang mutakhir agar pemustaka dapat tertarik untuk memanfaatkan perpustakaan karena mereka mengetahui bahwa di perpustkaan mereka dapat memperoleh ilmu pengetahuan, informasi, serta hiburan yang mendukung pekerjaan dan menambah pengetahuan.

Semua koleksi yang ada pada kantor Dinas Perpustakaan dan Kearsipan Kabupaten Kepulauan Selayar termasuk koleksi pada layanan perpustakaan keliling terapung diolah terlebh dahulu pada bagian pengolaha bahan pustaka. Pengolahan dimulai pada inventarisasi, klasifikasi, katalogisasi, dan shelving. Ada koleksi untuk perpustakaan umum (menetap). Ada koleksi untuk perpustakaan keliling, baik perpustakaan keliling darat maupun laut mempunyai koleksinya masing-masing. Apabila ada koleksi bahan pustaka yang rusak atau cacat, maka koleksi tersebut dikumpulkan kemudian diserahkan pada bagian pelestarian bahan pustaka untuk diperbaiki.

Koleksi bahan pustaka pada perpustakaan keliling terapung diperoleh dengan dua cara, yaitu pembelian dan sumbangan. Dinas Perpustakaan dan Kearsipan Kabupaten Kepulauan Selayar setiap tahunnya selalu melakukan pengadaan koleksi bahan pustaka melalui anggaran dari pemerintah daerah. Selain pengadaan bahan pustaka, perpustakaan juga mendapatkan sumbangan koleksi dari perpustakaan nasional dan perpustakaan provinsi. Dalam pengadaan koleksi bahan pustaka, perpustakaan harus memperhatikan koleksi-koleksi yang akan dipesan atau dibeli. Seperti yang dikemukakan oleh Ali (2006: 123) bahwa isi bahan pustaka tidak mengandung propaganda politik, mengkritik, menentang dan meberi tafsiran yang salah sehingga menimbulkan perpecahan dalam kehidupan bermasyarakat, berbangsa, dan bernegara.

\section{Berdasarkan Layanan}

Perpustakaan keliling terapung ini menggunakan system layanan terbuka agar memudahkan pemustaka dalam mencari dan mengambil koleksi yang mereka butuhkan. Hal ini sesuai dengan yang dikemukakan oleh Istiana (2014: 8) bahwa pada system layanan terbuka, pemustaka mencari sendiri buku yang diinginkannya 
untuk dipinjam atau dibaca di ruang baca. Dengan begini tatanan buku pada rak akan mudah berubah, tidak rapi, dan memiliki resiko kehilangan yang besar. Tetapi dengan adanya kebebasan untuk melihat bentuk dan isi buku, pengguna lebih tertarik untuk membaca.

Ada 3 jenis layanan yang disediakan pada layanan perpustakaan keliling terapung, antara lain layanan baca, layanan sirkulasi, dan layanan referensi. Pemustaka dapat membaca buku di dalam kapal maupun di sekitaran kapal. pemustaka juga bia meminjam koleksi yang meeka inginkan, tetapi ada beberapa koleksi yang tidak bisa dipinjam. Koleksi referensi hanya bisa dibaca di perpustakaan saja. Koleksi referensi diberikan tanda berwarna merah pada punggung buku. Di dalam buku Panduan Penyelenggaraan Perpustakaan Keliling (Perpustakaan Nasional, 2013: 15-16) dikatakan bahwa jenis-jenis layanan yang diusahhakan ada pada perpustakaan keliling terapung, antara lain layanan sirkulasi dan layanan referensi. Pemustaka dapat meminjam koleksi yang mereka butuhkan. Tetapi untuk koleksi referensi, tidak untuk dipinjamkan, seperti contohnya majalah, koran, ensiklopedi, dan lain-lain.

Layanan perpustakaan keliling dilaksanakan satu sampai dua kali dalam seminggu, karena kapal yang memakan banyak bahan bakar ketika melakukan pelayanan. Layanan ini juga harus berpatokan pada cuaca. Pelayanan hanya akan dilakukan apabila cuaca dalam kondisi baik. sebab keselamatan adalah hal utama yang perlu diperhatikan. Itulah sebabnya dalam pelayanan perpustakaan keliling terapung tidak menetapkan hari tertentu.

Adapun kegiatan-kegiatan khusus yang dilaksanakan pada layanan perpustakaan keliling, antara lain lomba mewarnai, story telling, serta pemutaran film-film edukasi. Kegiatan-kegiatan ini bertujuan untuk memberikan hiburan kepada pemustaka agar mereka tidak merasa bosan dengan kegiatan yang itu-itu saja di perpustakaan. Tetapi kegiatan ini hanya dilaksanakan pada waktu-waktu tertentu mengingat salah satu tujuan perpustakaan keliling yang dikemukakan oleh Mudjito (1992: 5) ialah meningkatkan minat baca dan mengembangkan cinta buku kepada masyarakat.

\section{Berdasarkan Pemustaka}

Layanan perpustakaan keliling terapung Dinas Perpustakaan dan Kearsipan ini tidak membeda-bedakan setiap pengunjung yang datang ke perpustakaan, juga tidak dikenakan syarat-syarat tertentu bagi setiap pengunjungnya. Pemustaka hanya diwajibkan mengisi daftar buku pengunjung setiap kali datang ke perpustakaan keliling terapung ini. Hal ini dikemukan oleh Maulana (2017: 23) bahwa layanan perpustakaan keliling bersifat terbuka, karena perpustakaan keliling melayani semua lapisan masyarakat tanpa membedakan status sosial, budaya, ekonomi, pendidikan, maupun status-status lainnya. Semua masyarakat tanpa memandang usia, bebas memanfaatkan layanan jasa perpustakaan keliling. 
Layanan yang diberikan oleh petugas perpustakaan sudah sesuai dengan harapan para pemustaka. Petugas perpustakan yang bertugas selalu bersikap ramah, menyampaikan sesuatu dengan baik-baik, serta membantu pemustaka yang mengalami kesulitan. Hal ini sesuai dengan yang dikemukakan oleh Arif (2008: 1516) bahwa ada 5 hal pokok yang perlu diperhatikan pada layanan perpustakaan keliling, antara lain kecepatan, ketepatan, kebenaran, keramahan, dan kenyamanan/keamanan. 5 hal ini yang harus diterapkan oleh pustakawan atau petugas pada perpustakaan agar layanan perpustakaan keliling terapung berjalan dengan baik dan pengunjung nyaman jika berkunjung ke perpustakaan.

Layanan perpustakaan keliling terapung membawa pengaruh tersendiri kepada masyarakat, seperti anak-anak sering membaca sehingga ada peningkatan minat baca pada anak pulau dan masyarakat tidak merasa ketinggalan informasi. Hal ini sesuai dengan salah satu tujuan dari perpustakaan keliling seperti yang dikemukakan oleh Mudjito (1992: 5) ialah untuk meningkatkan minat baca dan memperkenalkan jasa perpustakaan kepada masyarakat, sehingga tumbuh budaya untuk memanfaatkan jasa perpustakaan.

\section{F. Daftar Pustaka}

Ali. Aksentuasi Perpustakaan dan Pustakwanan. Jakarta: Sagung Seto, 2006.

Arsana, I Made Suka. "Evaluasi Layanan Perpustakaan Keliling pada Dinas

Kearsipan dan Perpustakaan Kabupaten Bandung." Jurnal Ilmiah D3 Perpustakaan, 2017:1.

Istiana, Purwani. Layanan Perpustakaan. Yogyakarta: Penerbit Ombak, 2014.

Maulana, Huzamir Irham. Persepsi Pemustaka terhadap Layanan Perpustakaan Keliling Dinas Perpustakaan dan Kearsipan Provinsi Banten. Jakarta: UIN Syarif Hidayatullah Jakarta, 2017.

Mudjito. Panduan Penyelenggaraan Perpustakaan Keliling. Jakarta: Perpustakaan Nasional RI, 1992.

Perpustakaan Nasional. Panduan Penyelenggaraan Perpustakaan Keliling. Jakarta: Perpustakaan Nasional, 2013.

- Pedoman Penyelenggaraan Perpustakaan Umum. Jakarta: Perpustakaan Nasional, 2000.

Pusat Bahasa Departemen Pendidikan Nasional. Kamus Besar Bahasa Indonesia. Jakarta: Balai Pustaka, 2007.

Rakib, Fatmawati A. "Kepuasan Pemustaka terhadap Layanan Perpustakaan Keliling Terapung (Studi Kasus Kota Ternate)." Jurnal Ilmu Perpustakaan, 2013.

Rakib, Rahmawati. "Kajian Pemanfaatan Layanan Perpustakaan Keliling sebagai Upaya Peningkatan Minat Baca Masyarakat di Kelurahan Tinoor 1 Kecamatan Tomohon Utara Kota Tomohon." e-journal Acta Diurna, 2017: 6.

Sugiyono. Metode Penelitian Kuantitatif, Kualitatif, dan R\&D. Bandung: Alfabeta, 2017. 
-. Metode Penelitian Kuantitatif, Kualitatif, dan R\&D. Bandung: Alfabeta, 2018.

- Metode Penelitian Pendidikan (pendekatan Kualitatif dan Kuantitatif R dan D. Bandung: Alfabeta, 2003.

Tim Penyusun. Kamus Besar Bahasa Indonesia (Ed. 3: Cet. Ke-2). Jakarta: Pusat Bahasa Depdiknas, 2002. 